\title{
U.S. Geological Survey Ground-Water Resources Program, 2001
}

Ground water is among the Nation's most important natural resources. It provides drinking water to urban and rural communities, supports irrigation and industry, sustains the flow of streams and rivers, and maintains riparian and wetland ecosystems. In many areas of the Nation, the future sustainability of ground-water resources is at risk from over use and contamination. Because ground-water systems typically respond slowly to human actions and climate variability, a long-term perspective is needed to manage this valuable resource. The U.S. Geological Survey Ground-Water Resources Program provides regional evaluations, fundamental data, and predictive tools to help assure the sustainability of our Nation's ground-water resources.

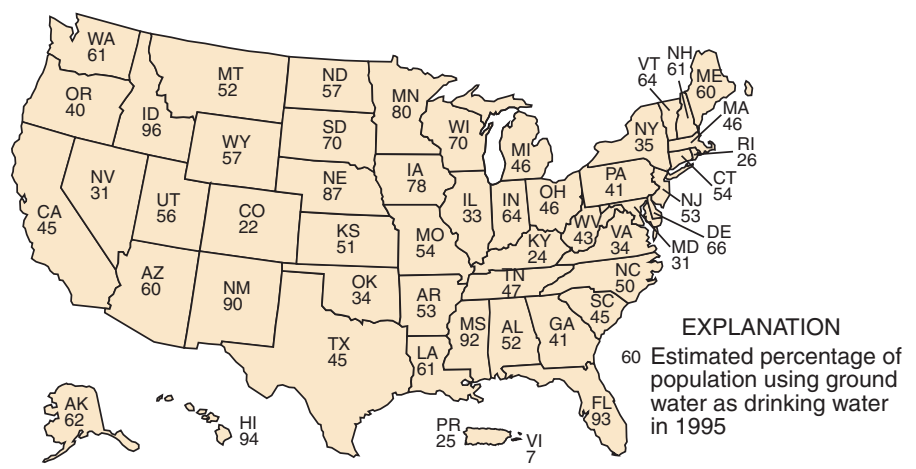

Estimated percentage of population using ground water in each State, Puerto Rico, and the U.S. Virgin Islands

\section{Priorities for Regional Ground-Water Evaluations}

Many ground-water systems extend across county, State, or other political boundaries. Despite this fact and the national importance of ground water, there is little ongoing assessment of ground-water resources availability at regional and national scales (National Research Council, 2000).

From 1978 to 1995, the U.S. Geological Survey (USGS) developed quantitative assessments of 25 of the Nation's most important regional aquifer systems, as part of the Regional Aquifer-System Analysis (RASA) Program. Most of the RASA assessments are 10 to 20 years old, and ground-water issues have increased in scope as competing demands on the resource have grown.

Concerns by Congress about declining efforts to evaluate the Nation's principal aquifers led to a 1998 USGS Report to Congress that outlines a strategy for addressing key regional issues about the Nation's aquifers, including the effects of lowered water levels and reductions in ground-water storage, saltwater intrusion, land subsidence, and reduced ground-water discharge to streams.
Following the Report to Congress, the National Research Council (NRC) conducted an evaluation of the Ground-Water Resources Program and, in November 2000, presented their findings in a report titled "Investigating Groundwater Systems on Regional and National Scales." Based on the report to Congress and the NRC findings, the following seven scientific issues have been identified as high priority for the Ground-Water Resources Program.

1) Support for Aquifer Management Decisions-As pumping and other stresses placed on our ground-water resources intensify, new approaches being used to optimize ground-water extraction while limiting undesirable effects such as depletion of groundwater reserves, land subsidence, and harm to ecosystems. Innovations in artificial recharge, water reuse, and conjunctive use of ground-water and surface-water resources are leading to new challenges for USGS scientists to provide the data analyses, and predictive tools to support sound aquifer management decisions.

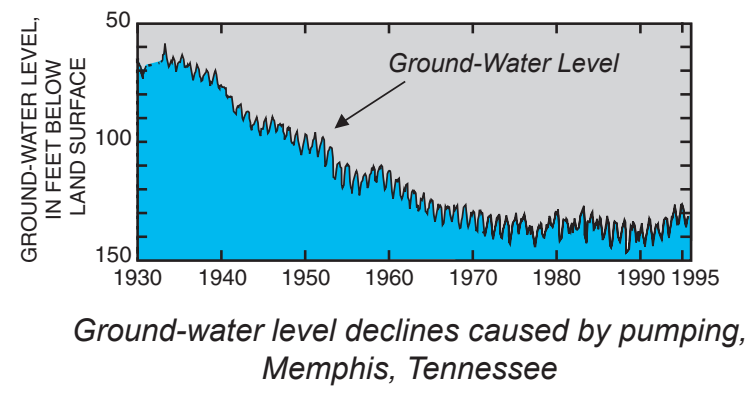

2) Natural Ground-Water Recharge-Information about the amount of water entering (recharging) the Nation's aquifers is vital, but the recharge rates are difficult to quantify. Improved knowledge of recharge processes, development and testing of new recharge estimation techniques, and methods to scale up sitespecific recharge estimates to regional values are needed.

3) Ground-Water Flow in Shallow Aquifers-Ground water is pumped from shallow aquifers to supply water to homeowners with private wells, some municipalities, and agricultural users throughout much of the United States. These shallow aquifers are particularly vulnerable to contamination from human activities and sensitive to droughts and climate change.

4) Saltwater Intrusion-Ground-water pumping has caused saltwater intrusion in the majority of U.S. coastal States, as well as some inland areas. As coastal cities grow, this problem is likely to become increasingly important. 
5) Ground-Water and Surface-Water Interaction-It is now recognized that nearly all surface-water features (streams, lakes, reservoirs, wetlands, and estuaries) interact with ground water. A fundamental understanding of these interactions is needed to evaluate their effects on water availability and the environment and to support watershed planning and management.

6) Ground Water in Karst and Fractured-Rock Aquifers-New methods are needed to help understand ground-water flow in karst and fractured-bedrock aquifers, which are the principal aquifers in many parts of the Nation. Many ground-water issues are amplified in fractured-rock aquifers because responses to pumping stresses and contamination can be more rapid than in aquifers where water flows through material such as sand and gravel.

7) Improved Hydrogeologic Frameworks-Ground-water movement is affected to a large degree by the properties of the rocks and soils through which the water flows. More maps that accurately show the geology in three-dimensions, as well as improved conceptual and statistical models of the geologic framework of aquifers, are needed to adequately assess groundwater resources and determine the effects of ground-water withdrawals.

\section{New Models, Field Techniques, and Data for Ground-Water Evaluations}

Evaluation of the issues listed above will require new methods of collecting and analyzing ground-water data. Government agencies, institutions, and private companies around the world use models developed by the USGS for simulating ground-water flow and contamination. As computer technology improves and new issues emerge, improvements are needed to better integrate models with advanced geographic information systems and hydrogeologic data bases.

"...hydrogeologists in WRD were largely responsible for the development, testing, and widespread application of numerical models of groundwater flow and contamination in the 1970-1980s. Their work has disseminated into the private sector and provides one of the best examples of the USGS's innovations bearing fruit in the private sector...The USGS is in an excellent position to manage true integration in the application of environmental models." (National Research Council, 2001)

Development of new field techniques also continues to be a high priority of the program. These techniques include geophysical methods for ground-water studies and ground-water age-dating methods to determine aquifer properties and to understand the interaction of ground water and surface water.

Comprehensive, long-term data bases are needed to support management of the Nation's resources for ground-water. Datarelated priorities for the Ground-Water Resources Program include 1) improved water-level monitoring of major aquifers, 2) greater access to ground-water data through the Internet, and 3) development of systems for storage and presentation of the threedimensional extent of aquifers and their hydrologic characteristics.

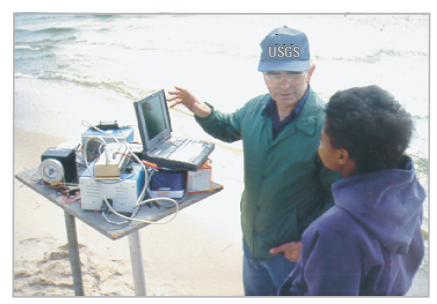

USGS hydrologist demonstrates collection

of ground-water data

\section{Enhanced Program Activities}

Congress provided additional funding for the Ground-Water Resources Program in fiscal year 2001 to begin to address some of the high-priority ground-water issues. This additional funding is supporting the following activities across the Nation.

Hydrogeologic characterization of alluvial basins in the arid Southwest

Assessment of ground-water and surface-water interaction related to irrigation in the Methow Valley, Washington

Development and testing of new geophysical methods for monitoring saltwater intrusion and ground-water discharge to coastal bays in Massachusetts, Maryland, and Delaware

Data collection and model development for saltwater intrusion in Virginia, North and South Carolina, Georgia, and Florida

$\square$ Fractured-rock aquifer analysis and related geologic mapping in Connecticut

Studies of ground-water depletion and water use for the High Plains Aquifer in Wyoming, South Dakota, Colorado, Nebraska, Kansas, Oklahoma, Texas, and New Mexico

Analysis of ground-water and surface-water interaction in Indiana and Michigan using new three dimensional geologic maps from the Central Great Lakes Geologic Mapping Coalition

Evaluation of the importance of microbiological processes related to regional ground-water-flow systems, especially for karst aquifers

Overview of water issues for caves and springs in the Nation's parks

Improved estimation of recharge rates in the eastern United States

- Norman G. Grannemann

\section{References}

National Research Council, 2000, Investigating groundwater systems on regional and national scales: Washington, D.C., National Academy Press, 143 p.

National Research Council, 2001, Future roles and opportunities for the U.S. Geological Survey: Washington, D.C., National Academy Press, $179 \mathrm{p}$.

\begin{tabular}{|} 
For additional information about \\
the USGS Ground-Water Resources Program, \\
please see http://water.usgs.gov/ogw/ \\
or contact: \\
Chief, Office of Ground Water \\
U.S. Geological Survey \\
411 National Center \\
12201 Sunrise Valley Drive \\
Reston, VA 20192 \\
\hline
\end{tabular}

